\title{
Social and pedagogical aspects of the development of inclusive education
}

\author{
Olena Budnyk, ${ }^{a}$ (i) \\ Serhii Sydoriv ${ }^{b}$
}

\begin{abstract}
The article substantiates theoretical and practical aspects of implementing inclusive education in the conditions of integration of Ukraine and other former Soviet countries into a global educational space, and also characterizes important socio-pedagogical aspects of the inclusive environment. It emphasizes a demand for forming a new philosophy of education with regard to changing attitudes towards persons with disabilities, especially in post-Soviet countries, as remaining traditional views and beliefs of today concerning teaching students with disabilities and their biased perception in society are still dominant. Gender stereotypes about inclusive education that characterize the mindset of a particular nation are also considered. Socio-pedagogical barriers of inclusion are presented. The article highlights important aspects of establishing an effective pedagogical cooperation between schools and families of students with special educational needs (SEN) and suggests tentative forms of work with parents at inclusive schools. The authors offer examples of the practical use of didactic materials in ESL/EFL teaching at elementary school, in particular inclusive graphic posters and audio-visual aids for forming democratic values and tolerant attitudes towards students with disabilities and SEN.
\end{abstract}

Keywords: inclusive education, socialization, socio-pedagogical interaction, pedagogy of tolerance, students with disabilities

\section{Sociální a pedagogické aspekty rozvoje inkluzivního vzdělávání}

Abstrakt: Tento článek se zabývá teoretickými a praktickými aspekty zavádění inkluzivního vzdělávání $v$ podmínkách integrace Ukrajiny a dalších zemí bývalého Sovětského svazu do globálního vzdělávacího prostoru, a také charakteristikou důležitých socio-pedagogických aspektů inkluzivního prostředí. Zdůrazňuje požadavek na vytvoření nové filozofie vzdělávání, která by zohledňovala měnící se postoje vůči lidem s postiženími, a to především $v$ postsovětských zemích, protože ve zdejší společnosti stále dominují přetrvávající tradiční názory a postoje k výuce studentů s postižením a jejich subjektivní vnímání. $\checkmark$ potaz byly vzaty $\mathrm{i}$ genderové stereotypy o inkluzivním vzdělávání, které jsou charakteristické pro smýšlení konkrétního národa. Dále jsou zde prezentovány socio-pedagogické bariéry inkluze. Článek zdůrazňuje důležité aspekty zavedení efektivní pedagogické spolupráce mezi školou a rodinou studentů 
se speciálními vzdělávacími potřebami (SVP) a navrhuje prozatímní způsoby práce $\mathrm{s}$ rodiči $\mathrm{v}$ inkluzivních školách. Autoři nabízí příklady praktického využití didaktických materiálů při výuce angličtiny jako druhého/cizího jazyka na základních školách, obzvláště inkluzivní grafické plakáty a audio-vizuální pomůcky pro formování demokratických hodnot a tolerantního prístupu ke studentům s postižením a SVP.

Klíčová slova: inkluzivní vzdělávání, socializace, sociopedagogická interakce, pedagogika tolerance, studenti s postižením

\section{Introduction}

Implementation of inclusive education is an ongoing process and a dominant trend in many countries of the world. Hence the integration of countries into the global educational space requires formation of a new philosophy of education based on humanization, tolerance and modernization of education systems, in order to provide quality services for various stakeholders, including those with special educational needs. Most countries in Western Europe, the USA, Canada and others celebrating their diversity and multiculturalism have been defining inclusive education for students with disabilities as the dominant form of education since the previous century. Inclusive education in the Nordic countries (Sweden, Denmark, Norway, Iceland and Finland) is one of the most valuable areas of education and social policy. The introduction of inclusive education as a comprehensive process in Scandinavia dates back to the second half of the 20th century, when special education became unable to meet all the requirements of a healthy society with equal opportunities for everyone (Andriichuk, 2017).

Some countries of Eastern and Central Europe have long abandoned totalitarian regimes of the past and are displaying positive advances in inclusive practices. This provides grounds for determining educational prospects of inclusion, taking into account ongoing socio-pedagogical challenges. Various countries have different needs and peculiarities; some EU member states lag behind, but all show constant progress towards equality in education. An overview of national education in Lithuania states that all children and youth with special education needs should have the opportunity to study in different types of schools and in a favorable learning environment, following formal and non-formal curricula ("UNESCO program," 2019).

There are still difficulties in resolving problems of inclusion in both the theoretical and practical context in the post-Soviet space and some countries of Eastern Europe. This includes revising and updating the regulatory framework for inclusive education, developing educational and methodological support for working with students with special educational needs, applying rules and principles of universal design to the infrastructure and learning environment of educational institutions, allocating funding for social initiatives for people with disabilities, etc. Society should take into consideration the interests and needs of persons with disabilities, along with representatives of "socially vulnerable groups" (orphans, persons with behavioral disorders, children whose parents have disabilities, students from low-income and migrant families, those with disadvantaged social backgrounds, etc.). The education of today needs to reflect the demands of social justice and develop benchmarks for differentiation of the educational process and individualized social and pedagogical programs.

The aim of the article is to substantiate the social and pedagogical aspects of introducing inclusive practices in general education institutions, both theoretically and empirically. 


\section{Research methods}

The comparative method has made it possible to study international experiences in implementing inclusive education. The application of this method enables systematization of research data on social and educational strategies of inclusion, and ensures forward-looking conclusions about theoretical and practical aspects of the development of inclusive education in the context of reforming the system of national education, while taking into account international standards.

Content analysis has been used to analyze and generalize scientific, pedagogical, psychological and educational literature on inclusion of students with disabilities, published during the last decade, within the socio-pedagogical context.

Hermeneutic analysis has enabled us to highlight the socio-pedagogical foundations of the development of inclusive education, within the framework of mutual understanding and establishment of a constructive pedagogical cooperation among all stakeholders of the educational process.

\section{The problem of socialization in the inclusive process}

European teaching practice has had a certain tradition of adapting the educational environment to the needs and demands of students with disabilities, and of maintaining a high level of pedagogical interaction and psychological support based on cooperation and co-creation in an inclusive classroom. Recent decades showed significant improvement and progress with regard to inclusion in the Czech Republic, the USA, Finland, Japan, and Canada. However, concerning the latter, the effectiveness of inclusive education in different Canadian provinces is not always high. Although the overwhelming majority of the citizens of the country endorse the idea of inclusion and understand the importance of socializing "special" students and forming a tolerant attitude towards them, a significant proportion of the population still supports traditional segregation approaches to teaching students with mental and physical disorders (Lyons, Thompson, \& Timmons, 2016). This is also true for the USA - there are states that generally do better at inclusion (Minnesota, Massachusetts, California, etc.) than others (Alabama, Mississippi, Wyoming, etc.). Concerning post-Soviet countries, the socialization of persons with disabilities is very low, being mainly visible in capital cities. Socializing children with disabilities in schools around the world is considered an important task of providing quality education for all and creating conditions for satisfying the cognitive needs of students in the least restrictive environment. In mainstreaming, traditional attitudes and beliefs regarding teaching students with disabilities, as well as their perception in society, play an important role. This is also true with teachers because their beliefs have a significant impact on their readiness to work in an inclusive educational environment (Main, Chambers, \& Sarah, 2016). Implementation of techniques of educational integration will make it possible to alleviate contradictions between the equal rights of persons with disabilities in choosing a life path, forms and methods of instruction, educational services and actual inequality of opportunities for different social groups (Kolupayeva, 2014, p. 11).

Dominant gender stereotypes that characterize the mentality of a particular nation or ethnic group play a significant role in the socialization of children with disabilities in an inclusive classroom. Today, there is no doubt that every person, regardless of his/her origin, religion, beliefs, nationality, etc., has an equal right to a quality education. However, many children with disabilities in countries with low and middle income are still deprived of educational opportunities (Budnyk, 2017). Gender issues are crucial in countries where human rights are often neglected and are, alongside disability, the main factors influencing inclusive education. For example, in Western and Eastern Africa (Guinea, Sierra Leone, Nigeria, Zambia, etc.), gender stereotypes often do not allow a child to obtain an education because of his/her developmental, intellectual, or physical disability. According to the findings of the research, boys and girls with a disability experienced cases of social isolation in the educational environment more frequently. Among students with disabilities, girls experience more emotional 
trauma due to social prejudices about their educational potential, and they are subjected to more sexual violence. Thus, for effective implementation of inclusive education, creating a safe school environment for all students, as well as overcoming gender stereotypes regarding the education of children with special educational needs, is crucial (Hui, Vickery, Njelesani, \& Cameron, 2017). Romanian scholars argue that society is still prone to a segregationist approach to education for children with disabilities. In Romania, the problem of training teachers of special education / inclusive education is also acute. That is, it involves the formation of professional psychological, pedagogical and methodological competences that allow them to effectively implement an individual approach to working with students with special needs (Blândul \& Bradea, 2017, p. 337).

In many countries, particularly in Eastern Europe, there are certain difficulties in implementing inclusive education because of the inability of schools to react effectively to rapid changes: introducing information and communication technologies, pedagogical innovations regarding the nature and content of teaching, new strategies for pedagogical interaction based on person-oriented education, etc. Post-Soviet countries have actively started to implement inclusive education only in the last decade, so it is too difficult to overcome the stereotypes mentioned above. "A truly inclusive approach to education creates a balance between ensuring that students receive the instruction they need to make progress academically, and ensuring that they experience a sense of belonging and social acceptance within their schools and classrooms" (Tichá, Abery, \& Kincade, 2018, p. 47). When a person with a disability leaves school and starts living independently, the social skills and emotional attitudes obtained while being in an educational environment will help him / her to be an active community member.

\subsection{Social and pedagogical barriers of inclusion}

Merely placing students with disabilities in inclusive classrooms is not sufficient to allow for their social inclusion, and other supports need to be in place to facilitate their acceptance by, and belonging to, the peer group (Pavri \& Luftig, 2000).

The introduction of inclusive education is often hindered by many barriers ("A Guide for Ensuring Inclusion," 2019; Dalin, 1980). These barriers are still relevant, especially in developing countries

1. Value barriers. In the educational process, we are faced with the problem of value differences. This challenge arises when different categories of students are integrated into a regular educational institution: immigrants, students with disabilities, children from poor families, representatives of various ethnic, cultural and religious groups, etc. This can lead to obstacles to pedagogical communication and socialization in the educational environment, and thus there are certain conflict situations regarding implementation of learning strategies.

2. Power barriers. Introduction of any educational reform often leads to changes in the power structures, redistribution of certain duties and obligations, etc. Concerning inclusive education, this barrier is also present due to the involvement of multidisciplinary professionals in the inclusive process (teachers, teacher assistants, medical staff, social workers, school psychologists, etc.). Therefore, the effectiveness of an inclusive process will depend on a combination of team responsibility, mutual understanding, pedagogical expertise and so on.

3. Practical barriers. Inclusive education implies and requires, first of all, universal design and adaptation of the whole educational process, along with curriculum, methodological and resource support for the needs of students with disabilities. If these requirements are not met, resolving social and pedagogical problems of inclusion may face serious practical barriers.

4. Psychological barriers. In an educational process, there are often cases where its participants (teachers included) do not support innovations and resist any changes. Their traditional views do not allow proper psychological perception of the inclusive process. Psychological difficulties may arise in the systems "teacher - student with SEN," "parents - teachers working in the inclusive class," "students with disabilities - students without disabilities," "parents of children with disabilities - school 
administration," etc. Psychological barriers are of a specific nature, and overcoming them may demand much time and require professional assistance. At the same time, there are concerns about maintaining emotional and psychological comfort while teaching students with SEN. Teachers of students with emotional and behavioral disorders (EBD) face the challenge of managing core academics alongside maladaptive behavior that may be insurmountable without embedded support from mental health professionals (Hunter, Elswick, \& Casey, 2018).

Thus socio-psychological and pedagogical barriers that sometimes exist in education seriously affect the effectiveness of inclusion. After all, it is a teacher who should be able to facilitate the positive perception of students with special needs, and enhance their optimism and self-confidence in their strengths and learning skills. A positive atmosphere at school, a sense of security and support for parents, teachers and classmates help to overcome any conflicts.

It is no coincidence that scholars emphasize the importance of the emotional factor in educating teenagers in the inclusive process, forming their social-emotional competencies in a family, at school, and among peers (Budnyk, 2017). Studying the socialization of Spanish and Romanian students with disabilities, researchers have demonstrated that school and family have significant influence. At the same time, the family's low emotional influence, particularly among Moroccan women, suggests the deterioration of the institution and the existence of inter-generational differences. (Ayala \& Cala, 2017).

If students with disabilities are more isolated and/or rejected than their peers without disabilities, the question arises as to how acutely students with disabilities perceive and internalize such feelings of rejection when they occur. Put another way, when these students are actively rejected or ignored by their peers without disabilities, do they perceive and take to heart such rejection and what does that rejection make them feel about their future ability to initiate or sustain appropriate social relationships? (Pavri \& Luftig, 2000, p. 9).

Children with disabilities have a very acute feeling of being rejected. This can negatively affect learning progress and relationships with peers and teachers. Moreover, social rejection of a child with disabilities at the initial stage of his/her schooling, along with insufficient interaction with friends, may negatively impact his/her future, since such a child will suffer from self-consciousness and low selfesteem and will always feel uncertain of his/her abilities, fearing a situation of being re-excluded by society.

\subsection{Socio-pedagogical interaction of the teacher with the parents of students with disabilities}

An important aspect of organizing the work of a teacher in an inclusive class is the establishment of proper social and pedagogical interaction with parents of students who have peculiarities of psychophysical development. After all, parents are full participants in the educational process, especially in an inclusive school. They have the right to: choose educational institutions and forms of education for junior children; make decisions on participation in the innovative activities of a comprehensive educational institution; elect and be elected to bodies of public self-government of general educational institutions; apply to the relevant education management bodies with questions of education and raising children; and protect the legitimate interests of children (Budnyk, Chervinska, \& Blyznyuk, 2018).

The problem of the involvement of parents in the educational process deserves particular attention in an inclusive class (Parents May Underestimate Their Importance to the IEP Team; Parents Provide Critical Input; Parents Work More Closely With Their Children Than Other Adults Can; Parents Are the Best Advocates for Their Child; Parents Provide Comprehensive Insight for Transition Meetings, etc.) (Logsdon, 2019). After all, the education of children with special educational needs is a joint task of parents and teachers. Parents' positive attitude towards these activities certainly contributes to integration processes, both in school and in society as a whole. For the purposeful preparation of the 
family members of children with peculiarities of psychophysical development for active participation in the process of inclusive education, the following forms of teachers' work with parents are useful: conducting special trainings, purposeful conversations, lectures on raising the pedagogical culture of parents, developing appropriate methodological materials, viewing feature films on relevant topics, and organizing (if necessary) meetings with various specialists (medical workers, artists, priests, volunteers, social workers, etc.) (Budnyk, Chervinska, \& Blyznyuk, 2018). Social-pedagogical work with the family of a child with special educational needs should take into account that a student's academic progress and well-being depend to a large extent on the participation of parents in the process of socialization in the school environment. Parents' feedback and participation can help with an objective assessment of the adequacy of the requirements for providing educational services to their child, and for taking action in cases of maladaptation, social exclusion, and psychological and/or emotional stress.

Consequently, the cooperation of teachers and parents in an inclusive classroom provides for synchronization of the goals, tasks, methods, and forms of organization of the educational process, maintaining psychological comfort and proper social and pedagogical conditions for the development of children with disabilities.

\subsection{Pedagogy of tolerance in inclusive education: Case study from Ukraine}

"There is a clear need for teacher preparation programs to address the social acceptance of students with disabilities in the general education classroom and to provide teachers with strategies needed to facilitate the social functioning of all their students" (Pavri \& Luftig, 2000, p. 14). Pedagogy of tolerance is an important tool and a condition for effective implementation of inclusive education. In modern science, the phenomenon of tolerance is viewed in many aspects: philosophical, political, sociological, psychological, pedagogical. Accordingly, the following types of tolerance are distinguished: racial, class, ethnic, religious, geographical, educational, age, physiological and gender. (Tereschenko, 2013, pp. 17-18). However, in all these areas of research, tolerance is closely related to human features such as: patience, trust, empathy, altruism, benevolence, etc. (Todortseva, 2004). The pedagogy of tolerance is defined as the willingness to accept others as they are and interact with them on the basis of mutual understanding (Denysenko, 2018). The pedagogy of tolerance in an inclusive classroom is manifested primarily in the culture of communication of children, teachers, parents and others. After all, students should understand that in spite of differences, it is necessary to counteract, perceive and accept people as they are. Being tolerant may be a rather difficult task for students at elementary schools where children with disabilities study. They lack social skills and the ability to manage their emotional states, and sometimes they display high demands towards others and the surrounding world. Therefore, the pedagogy of tolerance is the direction in educational policy without which qualitative changes in education in general, and inclusive education in particular, are not possible.

The idea of pedagogy of tolerance shaped our case study, devoted to training pre-service teachers to develop tolerance and a positive attitude towards children with disabilities and introduce principles of inclusive education while teaching the English language at elementary school (Easton, 2019; McLean, 2019).

The purpose of the case study is to investigate and practice the means of conveying the ideas and principles of inclusive education to university students / pre-service educators, and ensuring their assimilation of these ideas and principles while they develop their course-projects on methods of teaching English to preschoolers and elementary school students.

The setting and participants. Course projects were carried out at the Ivano-Frankivsk college of the Precarpathian National University in Ukraine in the 2017/18 academic year. 20 students of the $4^{\text {th }}$ year of study majoring in Elementary Education and 20 students majoring in Preschool Education were involved in working on course projects in teaching the English language, with the application of the ideas of inclusive education and their approbation through pedagogical practice at various preschool and elementary school institutions in the city of Ivano-Frankivsk. 
The materials. The developed course project products were teaching aids, created or adapted for use in inclusive settings (authentic graphic or text posters, grammar tables, anchor charts), e-versions and guided recommendations for use in a classroom. An emphasis was placed on the accessibility of the teaching aids for students with various educational needs: visual disabilities, deaf and hard of hearing, developmental, intellectual and behavioral disorders. In particular, with regard to visual aids for students with reduced and deteriorated vision, the following features were taken into account: reduced speed of processing visual information, narrowing or disappearance of visual fields, irregular ocular movements, binocular and stereoscopic vision disorders, color blindness, difficulties in selection and differentiation of colors, sensitivity to contrast changes, and ability to perceive simultaneously various features and properties of objects when viewed (Fedorenko, 2016, p. 486).

The procedures. At a preliminary stage, the students were acquainted with the concept of inclusive education along with its principles and ideas, and an analysis of inclusion in Ukraine and the USA was made. The workshop-seminar Inclusion in Education in the USA and Ukraine: Moving Together, which was held in Ivano-Frankivsk on October 27-31, 2017 as a part of the ADA Inclusive Education Fellowship Program, greatly contributed to the motivation of students who studied the availability of modern aids for teaching English at the elementary level.

The aims of the study were defined: to analyze pedagogical conditions and methods of teaching English for preschoolers and elementary school students, study the availability of positive practices of inclusion in Ukraine and internationally, and suggest ways of incorporating ideas and principles of inclusive education into the educational process in regular and inclusive schools and kindergartens. The students worked in small groups of three, meeting with a teacher on a weekly basis, discussing ideas and ongoing challenges, collecting and analyzing information, developing activities and aids to teach particular grammar and lexical topics, and offering ways to meet the objectives.

While developing teaching aids in the form of graphic posters, the following factors were taken into account: visibility - dimensions of posters $(80 \times 180$ or $80 \times 120 \mathrm{~cm})$; font Sans Serif Arial Regular or Black, font size 32 and larger; color gamut (optimal combination of colors for students with amblyopia: red - yellow, with myopia: blue - white, yellow - black, green - white); elements of augmentative and alternative communication, Picture Exchange Communication system, core and fringe vocabulary. As they are used in inclusive educational institutions around the world, those are effective means of teaching English and training teachers and educators (Sydoriv, 2018).

An important feature of the course projects by pre-service teachers was the graphical and textual representation of persons with disabilities on posters for teaching the English language to children (text, visual, and moral and ethical components), which contributed to better communication and socialization of students. Inclusion at the nationwide level in Ukraine is just starting; the majority of teachers, students and parents have had no extensive experience of interacting with students who have disabilities, hence the posters may herald changes and introduce ideas and principles of inclusive education indirectly. "Differing curricular, pedagogical, and pupil evaluation practices emphasize different cognitive and behavioral skills in each social setting and thus contribute to the development in the children of certain potential relationships to physical and symbolic capital" (Anyon, 1980, p. 10).

During the case study, we drew on the idea of Zones of Regulations (Kuypers, 2011), introduced in schools in Minnesota, which help students recognize and deal effectively with uncontrolled and unproductive emotional states. Using certain evidence-based practices, such as visual supports, positive behavioral interventions and a Picture Exchange Communication system, as well as an emojis system created by the students and children's naive drawings, we have developed a table of zones of emotional regulation, incorporated into a study of conjugation of the infinitive "to be" in the present simple tense (see Figure 1). 


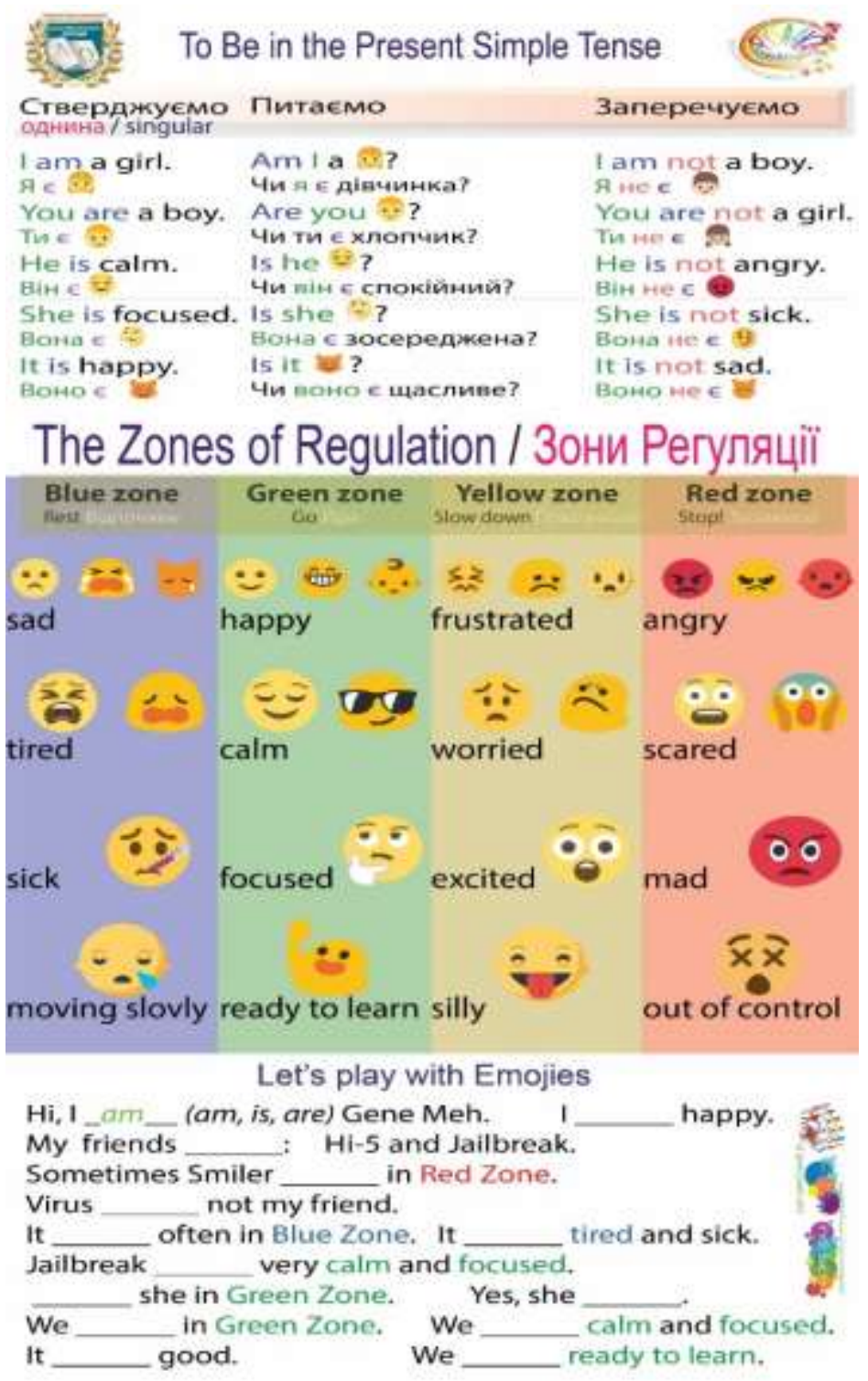

Figure 1. To be in the Present Simple Tense + zones of regulations

As a result, 12 inclusive graphic posters and 2 interactive tools for teaching English in elementary school have been produced that aim to develop communicative and socio-cultural competence, grammar and vocabulary: "Modal Verbs," "To Be in the Present Simple Tense + Zones of Regulations," "The Present Continuous Tense," "About Myself and My Friends," "Modal Verb Can," "Modals Can, May, Must," "Present Continuous," "Holidays and Celebrations," "What's the time?," "Past Simple," "Present Continuous."

Since children may not have seen students with disabilities at school before, we tried to incorporate ideas and principles of inclusive education in a curriculum indirectly, step by step. "Hidden curriculum is an implicit curriculum that expresses and represents attitudes, knowledge, and behaviors that are conveyed or communicated without awareness and are manifested indirectly by words and actions that are parts of the life of everyone in a society" (Alsubaie, 2015, p. 126). In the case study, we have tried to incorporate certain elements of hidden curriculum aiming at indirect communication of the principles and ideas of inclusive education. For instance, visual images of students with disabilities in the process of positive educational and social interaction with healthy peers, along with descriptive sentences, were selected to reach the goal: Kids can study together. I Were the children having fun during the break? | Nazar may not break things of other children. | Victor must not mock children who 
cannot speak well. | Can Vlad run and jump? No, he cannot. Vlad can ride a wheelchair, he has a disability. He moves very cool and fast in it. Vika and Vlad can go for a walk together, they are friends. | You may read my book. You have my permission, but do not tear it. | May I help and hold a door for you? | We must stop people who bully others. | Must I respect the rights of people whom I do not understand? I I can play football, but I cannot skate. | We are different, we are friends. We do not tolerate bullying. I We support and help each other. I Can Olya read ordinary printed books? No, she has a visual impairment. She can read braille books and listen to an audio text on her iPod. I Mike cannot play tennis; he can play volleyball. | Can kids study together? Yes, they can (see Figure 2).

Модальне дієслово CAN (могти) / Modal verb CAN

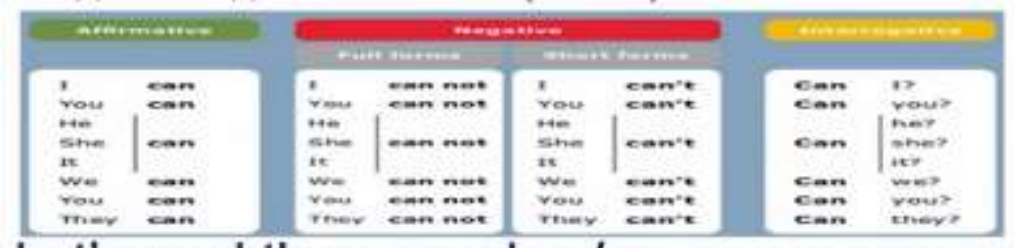

Let's read the examples / Прочитаймо приклади

1. This dog can draw.

Ця собака вміє малювати.

Can this dog draw? Yes, it can.

Чи вміє ця собака малювати? Так, вміє.

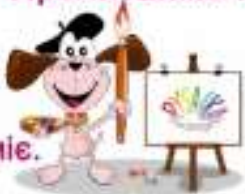

2. Mike can't play tennis, he can play basketball.

Майк не вміє грати у теніс, він може грати в баскетбол.

Can Mike play basketball? Yes, he can.

Чи може Майк грати в баскетбол? Так, може.

3. I can play football, but I can't skate.

Я вмію грати в футбол, але не вмію їдити на ковзанах

Can I skate? No, I can't.

Чи вмію я їздити на ковзанах? Нi, не вмію.

4. Children can study at school together. Діти можуть вчитися в школі разом.

Can children study at school? Yes, they can Чи можуть діти вчитися в школі?

Так, можуть.

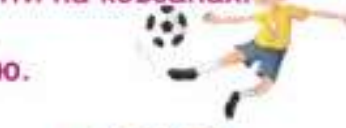

Listen and repeat / Слухай і повторюй

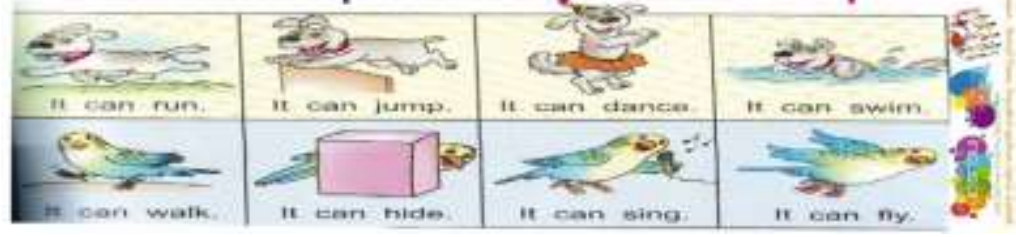

Figure 2. Poster for learning the modal Can

It has been anticipated that such educational aids help to raise awareness about inclusive education and disseminate ideas of tolerance, respect, mutual support, adherence to socially accepted rules of conduct, equal rights and opportunities, and gender and ability equality. They contribute to the productive cooperation of students in a classroom, motivate them to learn English, and increase the self-esteem of children with disabilities. Ideas about social norms and rules of behavior, the pedagogy of tolerance, and principles of Universal Design for Learning (alternative use of an audiobook, iPod, graphic icon) have also been used while developing and testing posters during teaching practice at school. The inclusive education posters have the potential for aesthetic and non-verbal communication of progressive ideas in class, during a break, or at parent meetings, guest visits or pedagogical practice (Sydoriv, 2018). 
Thus, the introduction of the proposed methodological tools in schools should serve the purpose of spreading ideas of inclusive education and more effective socialization of students with disabilities and special educational needs, as their number in the inclusive classrooms of Ukraine has tripled since 2016. The pedagogy of tolerance implies a productive dialogue and interaction with students who were previously excluded from school and society. "These students reported increases in reciprocal friendships and lower levels of social alienation after being in an inclusive classroom for the whole school year" (Pavri \& Luftig, 2000, p. 8).

The students had an opportunity to use the developed teaching aids during their pedagogical practice in preschool and school institutions. It should be mentioned that there were no students with special needs on an official list during their pedagogical practice, as there was a limited number of inclusive classrooms or schools. However, in subsequent years the number is expected to grow dramatically. Thus the student applied the developed aids to teaching English to healthy children; meanwhile, the ideas of inclusiveness were disseminated among students, teachers, school administration and parents.

The project's defense in spring 2018 highlighted different stages of work in the university and during educational practice. The results were as follows:

- the study demonstrated that such types of educational tasks contribute to the formation of tolerance towards students with disabilities and help to form an unbiased perception of special educational needs;

- the study highlighted the lack of well-developed educational aids to be used in inclusive settings, and initiated the first steps in rectifying this;

- the school students and preschoolers demonstrated progress in learning English grammar and lexical units with the use of the developed aids;

- the ideas and principles of inclusion were first introduced and assimilated for over 200 preschoolers and school students during pedagogical practice;

- $\quad$ the developed posters and methodological guides will be used, reproduced and modified as necessary by university graduates / pre-service teachers.

The conclusion. Ongoing research into the use of visual aids with inclusive educational strategies and techniques (UDL, peer-assisted learning, educational assessment and intervention, response to intervention, differentiated instruction, supporting student self-determination and social inclusion) is considered promising. These strategies, previously little known or used in Ukraine, need to be included in the teacher training curriculum for use at universities and for in-service training.

\section{Conclusions}

Implementation of inclusive education is characterized by difficulties and challenges, some of which are described in the article. Notwithstanding globalization processes, each country has its own needs and challenges with regard to social or educational inclusion.

Implementers need to take into consideration a number of factors, the majority of which are heavily influenced by the specific socio-economic and educational environment of the region or country where inclusion is being implemented, including available resources, the culture, and characteristics of students and families. Each country, either on its own or with supports, therefore needs to chart its own path toward inclusion based on its societal values, education legislation, and available supports (Tichá, Abery, \& Kincade, 2018, p. 55). 
The study highlights both the theoretical and practical aspects of implementing inclusive education, characterizes important aspects of establishing an effective pedagogical cooperation between schools and families of students with special educational needs (SEN), and suggests tentative forms of work with parents at inclusive schools. The case study from Ukraine highlights the development and practical use of didactic materials, in ESL/EFL teaching at elementary schools, that seek to introduce the ideas and principles of inclusive education and form democratic values and tolerant attitudes towards students with disabilities and SEN. Today, it is important to develop a student's creative personality and abilities, despite differences or special needs. At the same time, we include students with disabilities in a partnership to address specific learning tasks, including working on posters while learning English.

\section{The tentative forms of work with parents at inclusive schools are needed.}

Implementation of inclusive education in the socio-pedagogical aspect involves the following tasks:

- overcoming stereotypes in society that propagate a biased (negative) attitude towards students with special educational needs, with regard to their abilities and rights to education in regular schools within their local community;

- analyzing and implementing findings of ongoing socio-pedagogical research for identification of social and/or personal problems of a student with a disability, and an immediate response with professional psychological and pedagogical support;

- creating a welcoming educational environment aimed at compensating for the adverse socialization experience of students with special educational needs, providing proper assistance in creating favorable conditions for their adaptation / socialization in the school environment;

- ensuring social and pedagogical support for parents of children with disabilities;

- working with gifted children, especially those with special needs (developing their artistic, athletic or academic talents);

- $\quad$ organizing events for active leisure activities of students with disabilities, helping to establish friendly relations with peers and integrate them into society;

- $\quad$ sustaining social and pedagogical cooperation between school staff and parents of students with disabilities to meet the challenges of inclusive education at various levels;

- $\quad$ adapting educational and methodological support and modifying the educational process with the purpose of forming a new philosophy of education - the pedagogy of tolerance;

- holding diverse social and educational activities to promote inclusive education and partnership pedagogy, enhancing the pedagogical culture of the parents' community in order to reveal and promote tolerant attitudes towards children with disabilities and their parents.

Inclusive education is a global trend, having local peculiarities and challenges. Each country has its own unique and valuable experiences, and by sharing these, humanity can move towards a just and equal society, assisting and empowering each other. In Ukraine, the project Without Borders: Sustaining and Supporting An Inclusive Education Learning Community, with the support of the Institute for Community Integration, University of Minnesota and the US Embassy in Ukraine, and in partnership with the Ministry of Education of Ukraine, Ivano-Frankivsk college, Precarpathian National University, Kharkiv Humanitarian Pedagogical Academy, Kherson State University, Khmelnytskiy comprehensive secondary school №8, the "Step Into Life" charity organization and others, has been launched, and aims to create:

1. A dynamic inclusive education community of learning, composed of a network of education professionals in the field of inclusive education, along with parents. 
2. A Ukrainian National Inclusive Education Consortium composed of multiple universities committed to the implementation of inclusive education policies and practices, with the capacity to produce new educators with an understanding of inclusive education practices and the ability to effectively implement them, as well as the capacity to serve as a resource center for schools.

3. A variety of inclusive education schools located in the targeted regions that can serve as model sites that have been supported to showcase inclusive practices.

By including people with disabilities, we include ourselves in the prosperous future that is being prepared by today's preschoolers and school students.

\section{References}

A guide for ensuring inclusion and equity in education. (2019, February 28). UNESCO Publishing. Retrieved from https://unesdoc.unesco.org/ark:/48223/pf0000248254

Alsubaie, M. A. (2015). Hidden curriculum as one of the current issues of curriculum. Journal of Education and Practice, 6(33), 125-128.

Andriichuk, N. (2017). Historical background of inclusive education development in the Nordic countries. Journal of Vasyl Stefanyk Precarpathian National University, 4(1), 97-104. https://doi.org/10.15330/jpnu.4.1.97-104

Anyon, J. (1980). Social class and the hidden curriculum of work. Journal of Education, 162(1), 67-92. https://doi.org/10.1177/002205748016200106

Ayala, E. S., \& Cala, V. C. (2017). The impact of social capital in socio-emotional competencies of Spanish and immigrant adolescents from the southeast of Spain. International Journal of Inclusive Education, 21(8), 849-865. https://doi.org/10.1080/13603116.2017.1296035

Blândul, V. C., \& Bradea, A. (2017). Developing psychopedagogical and methodical competences in special / inclusive education teachers. Problems of Education in the $21^{\text {st }}$ Century, 75(4), 335-344.

Budnyk, O. (2017). Inklyuzyvne navchannya: Socialno-pedahohichnyj kontekst problemy [Inclusive Education: Sociopedagogical context]. In V. V. Zasenko \& A. A. Kolupayeva (Eds.), Osvita osib z osoblyvymy potrebamy: shlyaxy rozbudovy: zbirnyk naukovyx prac (pp. 71-80). Kyiv: Nasha Drukarnya.

Budnyk, O., Chervinska, \& I., Blyznyuk, T. (2018). Pedagogical collaboration of teachers and parents of children who have special educational needs in conditions of inclusive education. In A. Próchniak \& A. Suchocka, Problemy i perspektywy młodzieży we współczesnej Europie (pp. 85-93). Bydgoszcz: Słupsk.

Dalin, P. (1980). Limits to educational change. Educational Management Administration \& Leadership, 9(1), 141-143. https://doi.org/10.1177/174114328000900110

Denysenko, G. M. (2019, February 28). Pedagogichna tolerantnist' $v$ procesi pidgotovky 'majbutn ’ogo vchy'telya pochatkovy`x klasiv [Pedagogical tolerance in training a pre-service teacher of elementary school]. Retrieved from http://intkonf.org/denisenko-gm-pedagogichnatolerantnist-v-protsesi-pidgotovki-maybutnogo-vchitelya-pochatkovih-klasiv/

Easton, R. (2019, February 28). Collection of case studies on examples of good practice in teacher education with a focus on organisational aspects and integrated concepts of language education. Retrieved from http://archive.ecml.at/documents/213pubeaston_2001e.pdf

Fedorenko, M. I. (2016). Vymohy do drukovanoyi navchalnoyi literatury dlya ditej zi znyzhenym zorom [Guidance for printed textbooks for children with low vision]. Problemy suchasnoho pidruchnyka, 17, 485-493. 
Hui, N., Vickery, E., Njelesani, J., \& Cameron, D. (2017). Gendered experiences of inclusive education for children with disabilities in West and East Africa. International Journal of Inclusive Education, 22(5), 457-474. https://doi.org/10.1080/13603116.2017.1370740

Hunter, W. C., Elswick, S. E., \& Casey, L. B. (2018). Efficient wraparound service model for students with emotional and behavioral disorders: A collaborative model for school social workers and teachers. Children \& Schools, 40(1), 59-61. https://doi.org/10.1093/cs/cdx030

Kolupayeva, A. (2014). Specialna osvita v Ukrayini ta modernizaciya osvitnoyi haluzi. [Special education in Ukraine and modernization of education]. Osoblyva dytyna: Navchannya i vyxovannya, 3, 7-12.

Kuypers, L. (2011). The Zones of Regulation ${ }^{\circledast}$ : A curriculum designed to foster self-regulation and emotional control. San Jose, CA: Social Thinking Publishing.

Logsdon, A. (2019, February 28). The important role of parents in special education. Retrieved from https://www.verywellfamily.com/parental-importance-special-education-2162701

Lyons, W. E., Thompson, S. A., \& Timmons, V. (2016). 'We are inclusive. We are a team. Let's just do it': Commitment, collective efficacy, and agency in four inclusive schools. International Journal of Inclusive Education, 20(8), 889-907. https://doi.org/10.1080/13603116.2015.1122841

Main, S., Chambers, D. J., \& Sarah, P. (2016). Supporting the transition to inclusive education: Teachers' attitudes to inclusion in the Seychelles. International Journal of Inclusive Education, 20(12), 1270-1285. https://doi.org/10.1080/13603116.2016.1168873

McLean, H. (2019, February 28). Engaging and Inclusive Education: A Case Study. Senior Honors Theses. 578. Retrieved from https://digitalcommons.liberty.edu/cgi/viewcontent.cgi?article=1623\&context=honors

Pavri, S., \& Luftig, R. (2000). The social face of inclusive education: Are students with learning disabilities really included in the classroom? Preventing School Failure: Alternative Education for Children and Youth, 45(1), 8-14. https://doi.org/10.1080/10459880109599808

Sydoriv, S. (2018, October). Kursovi proekty z metodyky vykladannya anhlijskoyi movy yak zasib poshyrennya pryncypiv inklyuzyvnoyi osvity $v$ spivzvuchchi z ideyamy novoyi ukrayinskoyi shkoly [Coursework on methods of teaching English as a means of disseminating principles of inclusive education and the new Ukrainian school]. In I. Humenyuk, O. Dzhus, \& N. Kucherak (Eds.), Profesijna pidhotovka faxivciv u vymiri novyx osvitnix realij (pp. 396-404). Ivano-Frankivsk: NAIR.

Tereschenko, K. V. (2013). Tolerantnist' yak chy`nny’k rozvy'tku organizacijnoyi kul'tury`zakladiv osvity` [Tolerance as a factor in the development of the organizational culture of educational institutions]. In S. D. Maksymenko (Ed.), Actual problems of psychology (pp. 16-18). Kyiv: LADO.

Tichá, R., Abery, B., \& Kincade, L. (2018). Educational practices and strategies that promote inclusion: Examples from the U.S. Sociální pedagogika / Social Education, 6(2), 43-62. https://doi.org/10.7441/soced.2018.06.02.03

Todortseva, Y. V. (2004). Pedagogika tolerantnosti [Pedagogy of tolerance]. Odesa: SVD Cherkasov M. P.

UNESCO program Education for All 2015. (2019, February 28). Švietimo, mokslo ir sporto ministerija. Retrieved from https://www.smm.It/uploads/lawacts/docs/764_f5a0f788b5783d3f016d4b6de00dc418.pdf 